\title{
ANALISIS PENGARUH SERVICE RECOVERY TERHADAP LOYALITAS PELANGGAN DALAM JASA TELEPON SELULER
}

\author{
${ }^{1}$ Mia Antika, ${ }^{2}$ Kussudyarsana, ${ }^{3}$ Evita Dhewi Hananti \\ Fakultas Ekonomi dan Bisnis \\ Universitas Muhammadiyah Surakarta \\ 12antikamia28@gmail.com, ${ }^{2}$ kus165@ums.ac.id, ${ }^{3}$ Dhewi_Evita@yahoo.co.id
}

\begin{abstract}
Abstrak: Tujuan penelitian ini adalah untuk meneliti pengaruh service recovery pada trust dan loyalitas konsumen. Untuk memeriksa kaitan antara service recovery dan loyalitas pelanggan, penelitian ini menggunakan perspektif keadilan meliputi procedural justice, interactional justice, dan distributive justice. Setting penelitian ini adalah bisnis informasi dan teknologi. Penelitian ini diselenggarakan di area kotamadya Surakarta dengan konsumen operator komunikasi sebagai respondennya. Penelitian ini menerapkan convenience sampling dan melibatkan 150 responden yang dikelompokkan menjadi konsumen complain dan non-komplain. Analisis regresi digunakan untuk proses analisis data. Penelitian ini menyimpulkan bahwa procedural justice memiliki pengaruh signifikan terhadap kepuasan pelanggan. Sebaliknya, distributive dan interactional justice tidak memiliki pengaruh signifikan terhadap kepuasan pelanggan. Penelitian ini menemukan bahwa trust dan customer satisfaction memiliki pengaruh terhadap loyalitas pelanggan. Lebih lanjut, penelitian ini juga menemukan bahwa responden yang tidak mengajukan komplain lebih percaya dan loyal daripada konsumen yang mengajukan komplain jasa yang disediakan operator telepon. Hal ini menunjukkan bahwa service recovery gagal memperbaiki service failure.
\end{abstract}

\begin{abstract}
The objective of this research is to examine the impact of service recovery on trust and customer loyalty. To examine the connection between service recovery and customer loyalty, this research used justice perspective which includes procedural justice, interactional justice and distributive justice. The setting of this research is information technology business. The research was conducted in the area of Surakarta regency with the customers of phone operators as the research respondents. This research used convenience sampling and involved 150 respondents grouped by complaint and non-complaint customer. Regression analysis was used in this research to analyse the data. The research concluded that procedural justice have significant impact on customer satisfaction. In contrast, distributive and interactional justice did not have significant impact on customer satisfaction. This research also found that trust and customer satisfaction significantly impact customer loyalty. In addition, this result also found that non-complaint respondents put more trust and loyalty than customers who complaint to the service which is provided by the phone operator. This indicated that service recovery failed to fix service failure.
\end{abstract}

Keyword: Service Recovery, Service Failure, Customer Satisfaction, Trust, Customer Loyalty

\section{PENDAHULUAN}

Indonesia merupakan salah satu negara dengan pengguna handphone terbesar di dunia. Hal ini terjadi karena jumlah pengguna handphone lebih banyak dibandingkan dengan jumlah penduduk Indonesia sendiri. Jumlah penduduk Indonesia hanya sebesar 253 juta sedangkan pengguna handphone mencapai angka 270 juta. Sehingga sangat tidak mengherankan jika Indonesia dijadikan sebagai ladang bisnis seluler yang sangat menggiurkan. Bisnis seluler di Indonesia yang menggiurkan ini didominasi oleh bisnis operator GSM dan CDMA. Dan yang paling dominan penggunaannya adalah penggunaan operator GSM. Dimana terdapat 3 operator seluler terbesar di Indonesia yaitu Telkomsel, XL Axiata, dan Indosat. Ketiga operator seluler ini berlomba-lomba agar dapat meningkatkan jumlah pengguna layanannya. Berikut merupakan laporan jumlah pengguna dari masing-masing operator pada tahun 2014 pada kuartal pertama dan kuartal ketiga. 
Tabel 1.1

Jumlah Pengguna Layanan

\begin{tabular}{lccc}
\hline Operator Seluler & $\begin{array}{c}\text { Total pengguna pada } \\
\text { Q1 2014 (juta) }\end{array}$ & $\begin{array}{c}\text { Total pengguna pada } \\
\text { Q3 2014 (juta) }\end{array}$ & Persentase \\
Telkomsel & 132,7 & 139,2 & $4.9 \%$ \\
Xl Axiata & 62,9 & 58,3 & $7.3 \%$ \\
Indosat & 59,7 & 54,3 & $9.1 \%$ \\
mber:https://id.techinasia.com/laporan-finansial-operator-gsm-dan-cdma-terbesar-di-indonesia-q1-2014
\end{tabular}

Dari Tabel 1 dapat dilihat bahwa Telkomsel memiliki jumlah pengguna yang paling tinggi dengan peningkatan sebesar 4,9\%. Disusul kemudian dengan XL Axiata yang mengalami penurunan sebesar 7,3\%. Dan kemudian yang menjadi operator seluler terbesar ketiga adalah Indosat yang juga mengalami penurunan jumlah pelanggan sebesar 9,1\%. Jika dilihat dari data di atas dapat disimpulkan bahwa Indosat mengalami penurunan pada jumlah pelanggan yang cukup signifikan, hal ini menyebabkan Indosat belum mampu unggul dari 2 kompetitornya yaitu Telkomsel dan XL Axiata.

Salah satu produk dari Indosat adalah Indosat IM3. IM3 sendiri menguasai 2/3 dari keseluruhan pengguna Indosat. Fokus dari Indosat IM3 ini sendiri adalah teknologi dan value-added service dimana pelayanan ditekankan pada tarif harga yang super murah dan fitur-fitur yang dibuat untuk kalangan anak muda. Dengan adanya tarif murah, fiturfitur yang terkesan masa kini, dan fitur yang canggih ini tidak menjadikan IM3 mampu memuasakan seluruh penggunanya. Banyak keluhan yang berdatangan kepada IM3 sehingga membuat IM3 terperosok dalam slogan yang dibuatnya sendiri yaitu "sinyal kuat Indosat". Beberapa keluhan itu antara lain buruknya sinyal untuk penggunaan fitur seperti panggilan, SMS, BBM, E-mail, Internet Browser, dan lain-lain. Belum juga termasuk ketidaksesuaian janji tarif yang dipromosikan, serta fitur-fitur content provider yang mengganggu (Badiana, 2012). Keluhankeluhan ini merupakan sebuah bentuk dari kegagalan layanan atau service failure.

Service failure ini dapat terjadi karena banyak alasan seperti jasa yang ditawarkan tidak sesuai dengan yang dijanjikan. Bell dan Zemke (dalam Ogbonna et al., 2015) mengemukakan bahwa "kegagalan layanan terjadi ketika layanan yang diberikan tidak sesuai harapan pelanggan yang pada akhirnya memerlukan respon dari penyedia layanan dengan tujuan untuk pemulihan". Seperti yang Indosat IM3 alami yaitu kegagalan mengaplikasikan janjinya dengan slogan "sinyal kuat indosat" terhadap pelanggan. Indosat IM3 malah lemah dalam hal pelayanan mengenai sinyal yang dianggap bermasalah. Sehingga berdampak negatif terhadap citra perusahaan. Hal ini sesuai dengan pernyataan Mittal, Ross dan Baldasare (dalam Ogbonna et al., 2015) yang mengungkapkan bahwa "Kinerja negatif memiliki pengaruh yang lebih besar pada kepuasan dan intensitas pembelian pelanggan dibandingkan dengan kinerja positif". Berdasarkan hal tersebut, terdapat fakta yang sederhana dimana ketika pelanggan merasa kecewa atau tidak puas dengan pelayanan yang diberikan oleh penyedia layanan, maka perusahaan penyedia layanan tersebut akan kehilangan lebih dari nilai transaksi yang berikutnya. Bahkan sangat mungkin perusahaan tersebut dapat kehilangan keuntungan dalam jangka panjang dan juga pelanggan yang dimiliki bisa saja beralih ke penyedia layanan lain.

Salah satu upaya yang dilakukan perusahaann dalam menangani kegagalan layanan adalah melakukan pemulihan layanan (service recovery) terhadap penggunanya. Pemulihan layanan merupakan "istilah dari usaha-usaha sistematis yang dilakukan perusahaan untuk mengkoreksi permasalahan yang disebabkan oleh kegagalan pelayanan dan untuk mempertahankan pelanggan" (Lovelock, 2005). Hal serupa juga dikemukakan oleh Johnston dan Hewa (dalam Ogbonna et al., 2015) yang mendefinisikan service recovery sebagai "tindakan penyedia layanan untuk mengurangi dan atau memperbaiki kegagalan pelayanan pada pelanggan untuk memberikan layanan yang unggul yang memenuhi harapan pelanggan".

Service recovery yang efektif dan sesuai prosedur adalah serangkaian tahapan ataupun 
prosedur yang dapat membantu memecahkan permasalahan dan menangani pelanggan yang merasa kecewa terhadap pelayanan yang diberikan perusahaan. Komitmen yang dilakukan oleh perusahaan terhadap kepuasan pelanggan diharapkan bukan hanya berasal dari janji-janji belaka tetapi juga dari bagaimana tanggapan perusahaan pada saat terjadi sesuatu yang salah kepada pelanggan. Strategi service recovery sangat penting dimiliki perusahaan agar dapat mencapai kepuasan pelanggan. Kotler dan Keller (2006) mendefinisikan kepuasan pelanggan sebagai "perasaan suka atau tidak suka seseorang terhadap suatu produk setelah membandingkan prestasi produk tersebut dengan harapannya".

Kepercayaan pelanggan yang dihasilkan dari upaya pemulihan layanan pasca kegagalan layanan merupakan tujuan utama dari service recovery itu sendiri. Kepercayaan pelanggan dapat terbentuk dari akumulasi kepuasan, pengiriman layanan yang konsisten berkualitas, pemenuhan kebutuhan pelanggan, perlakuan jujur dan adil, dan keyakinan bahwa perusahaan bermaksud untuk memberikan perlakuan terbaik untuk pelanggan Berry et al.,(Choi dan La, 2013). Memiliki pelanggan yang percaya kembali bukanlah tujuan akhir. Tujuan akhir yang ingin dimiliki adalah mempunyai pelanggan yang tidak hanya percaya namun juga loyal terhdap perusahaan. Seperti yang dikemukakan oleh Tjiptono (dalam Nursyamsiah dan Virgostin, 2011) bahwa "kepuasan pelanggan akan memperoleh beberapa manfaat pokok yaitu reputasi perusahaan yang semakin positif dimata pelanggan dan masyarakat, serta dapat mendorong terciptanya loyalitas pelanggan". Memiliki pelanggan yang loyal tidak terlepas dari kepuasan yang diberikan oleh penyedia layanan. Hal ini akan berdampak pada jangka pendek dan jangka panjang seperti yang dikemukakan oleh Badawi (2012) yang mengungkapkan bahwa "kepuasan pelanggan merupakan salah satu aset penting dalam memiliki pasar dalam jangka pendek dan berkontribusi pada pertumbuhan pasar pada jangka panjang”. Oleh karena itu perusahaan harus meningkatkan pelayanannya agar pelanggan tidak kecewa. Seseorang dikatakan loyal apabila "pelanggan melakukan tindakan pembelian secara berulang dan teratur" Griffin (dalam Nursyamsiah dan Virgostin, 2011).
Oleh karena itu perusahaan haruslah terus berkomitmen untuk meningkatkan layanannya agar pelanggan yang selama ini dimiliki menjadi pelanggan yang tidak hanya puas, akan tetapi menjadi pelanggan yang loyal.

\section{TINJAUAN PUSTAKA}

Service recovery merupakan sebuah upaya yang dilakukan apabila terjadi kegagalan dalam pelayanan atau yang disebut service failure. Sejalan dengan pendapat Gronross (Siu et al., 2013) yang mendefinisikan pemulihan layanan adalah kegiatan dimana perusahaan berusaha untuk mengatasi keluhan pelanggan mengenai kegagalan layanan yang telah terjadi. Penanganan kegagalan layanan ini hendaknya dilakukan secara cepat sebagai langkah preventif agar pelanggan tidak beralih ke perusahaan lain atau ke penyedia jasa yang lain. Hal serupa juga dikemukakan oleh Lewis (Rashid dan Ahmad, 2014) yang menyatakan bahwa pemulihan layanan merupakan hal yang dilakukan untuk memecahkan masalah sebelum pelanggan mengeluh dan pergi dengan ketidakpuasan. Pemulihan layanan hendaknya tidak dilakukan secara spontan atau tanpa strategi khusus. Oleh karena itu dibutuhkan langkah-langkah yang sesuai dan tepat dengan prosedur-prosedur yang ada dalam melakukan pemulihan layanan. Sejalan dengan pendapat Lovelock (2005) yang mendefinisikan pemulihan pelayanan sebagai "istilah dari usaha-usaha sistematis yang dilakukan perusahaan untuk mengkoreksi permasalahan yang disebabkan oleh kegagalan pelayanan dan untuk mempertahankan pelanggan”.

Usaha-usaha pemulihan layanan barubaru ini menjadi hal yang menarik untuk diteliti, seperti misalnya teori keadilan telah menerima cukup banyak perhatian dalam studi pemulihan layanan. Teori keadilan telah digunakan sebagai dasar utama dalam pengembangan kerangka pemulihan layanan. Secara umum teori keadilan diwakili oleh tiga dimensi yaitu, procedural justice, interactional justice, dan distributive justice (Kau dan Loh, 2006) :

1. Procedural justice, yaitu atribut yang memfokuskan pada keadilan yang seharusnya diterima oleh konsumen ketika mengajukan komplain sesuai dengan aturan dan kebijakan yang telah 
ditetapkan perusahaan. Menurut McCollKennedy dan Sparks (Rashid dan Ahmad, 2014), keadilan prosedural adalah merupakan indikator penting dalam menunjukkan apakah prosedur atau prinsip-prinsip yang digunakan dalam pengambilan keputusan dilakukan secara adil untuk pelanggan. Menurut Tax et al (Rashid dan Ahmad, 2014) Procedural justice meliputi process control, decission control, accesibility, timing/speed, dan flexibility.

2. Interactional justice, yaitu atribut yang memfokuskan pada kelakuan atau respon yang ditujukan oleh perusahaan ketika berhadapan dengan konsumen yang mengajukan komplain. Definisi serupa dikemukakan oleh Tax et al.,(Siu et al, 2013) yang mendefinisikan keadilan interaksional dikaitkan dengan perlakuan antar pribadi pelanggan yang diterima selama berlakunya prosedur. Menurut Tax et al.,(Siu et al, 2013) Interactional justice meliputi explanation, honesty, politeness, effort, dan emphaty.

3. Distributive Justice, yaitu atribut yang memfokuskan padahasil dari penyelesaian service recovery, misalnya usaha apa yang dilakukan perusahaan untuk menangani keluhan pelanggan ketika perusahaan melakukan kesalahan, meskipun perusahaan harus mengeluarkan biaya yang besar sebagai pengganti kerugian. Distributive justice dapat diwujudkan dengan memberi kompensasi kepada pelanggan, misalnya dengan memberi discount, coupon, refunds, free gift, dan sebagainya (Blodgett.,et al. dalam Siu et al., 2013).

\section{Kepuasan \\ Pelanggan Satisfaction) \\ (Customer}

Kepuasan pelanggan merupakan wujud dari penilaian seseorang terhadap pelayanan yang diterimanya. Nilai yang diberikan oleh masing-masing pelanggan akan berbeda dari orang satu dengan orang yang lain. Kotler (2006) mendefinisikan kepuasan pelanggan sebagai "perasaan suka atau tidak suka seseorang terhadap suatu produk setelah membandingkan prestasi produk tersebut dengan harapannya". Hal serupa juga dikemukakan oleh Spreng et al., (Dimyati, 2015) yang menyatakan bahwa "kepuasan pelanggan adalah perasaan yang timbul ketika seorang pelanggan membandingkan persepsinya dari kinerja produk tertentu dengan harapannya". Jadi dapat disimpulkan bahwa kepuasan pelanggan sendiri diperoleh oleh seorang pelanggan apabila pelanggan tersebut merasa apa yang didapatkan dari perusahaan atau penyedia layanan sesuai dengan harapan dan ekspektasinya terhadap barang atau jasa tersebut.

\section{Kepercayaan (Trust)}

Kepercayaan (Trust) merupakan salah satu kunci penting dalam hal yang berhubungan dengan service recovery. Trust dianggap penting karena akhir-akhir ini sangat sulit memilih penyedia layanan jasa yang dapat dipercaya dan yang benar-benar kompeten terhadap layanannya. Hal ini sesuai dengan pendapat Liljander et al.,(Choi dan La, 2013) bahwa "kepercayaan merupakan hal yang sangat penting dalam konteks layanan karena karakteristik layanan seperti intangibility dan heterogeneity membuat sulit untuk memilih dan mengevaluasi penyedia layanan yang tepat". Kepercayaan pelanggan sendiri memiliki beberapa konsep yang dianggap penting didalamnnya. Coulter dan Coulter (Choi dan La, 2013) mendefinisikan konsep kepercayaan penyedia layanan seperti persepsi kerahasiaan dari penyedia layanan, kejujuran, integritas, dan standar etika yang tinggi.

\section{.Loyalitas Pelanggan (Customer Loyalty)}

Pada setiap perusahaan pastilah memiliki cara tersendiri agar dapat mencapai kepuasan bagi para pelanggan agar loyal terhadap perusahaannya. Menurut Oliver (Kotler dan Keller, 2006), loyalitas pelanggan merupakan "suatu komitmen untuk bertahan secara mendalam dengan melakukan pembelian ulang atau berlangganan kembali dengan produk atau jasa terpilih secara konsisten di masa yang akan datang, meskipun pengaruh situasi dan usaha-usaha pemasaran mempunyai potensi untuk menyebabkan perubahan perilaku". Loyalitas juga dapat diartikan pula sebagai suatu kesetiaan seseorang atas suatu produk, baik barang ataupun jasa tertentu. 
Loyalitas konsumen merupakan suatu bentuk dari kepuasan konsumen dalam menggunakan fasilitas maupun pelayanan jasa yang diberikan oleh perusahaan, serta untuk tetap menjadi konsumen dari perusahaan tersebut. Loyalitas dapat tercipta apabila seorang pelanggan percaya kembali terhadap penyedia layanan pasca kegagalan layanan dan adanya pemulihan layanan. Kepercayaan pelanggan dapat meningkat kembali setelah adanya upaya pemulihan layanan dengan prosedur yang benar seperti ungkapan Seiders dan Berry (Siu et al., 2013) bahwa "kepercayaan pelanggan setelah pemberian kompensasi pasca kegagalan adalah factor penting yang mempengaruhi kepuasan terhadap perusahaan secara keseluruhan".



Gambar 1

Kerangka Pemikiran Teoritis

Hipotesis yang diajukan dalam penelitian ini adalah sebagai berikut :

H1.a Procedural Justice berpengaruh terhadap Kepuasan atas Pemulihan Layanan.

H1.b Interactional Justice berpengaruh terhadap Kepuasan atas Pemulihan Layanan.

H1.c Distributive Justice berpengaruh terhadap Kepuasan atas Pemulihan Layanan.

H2.a Kepuasan atas Pemulihan Layanan berpengaruh terhadap Kepercayaan Pelanggan.

H2.b Kepuasan atas Pemulihan Layanan berpengaruh terhadap Loyalitas Pelanggan.

\section{METODE PENELITIAN}

Penelitian ini menggunakan desain survey yaitu suatu penelitian yang mengambil sampel dari suatu populasi dan menggunakan kuesioner sebagai alat pengumpulan data pokok. Tujuannya adalah mengumpulkan data secara efisien (Sekaran, 2006). Sedangkan menurut jenis data dan analisisnya adalah kuantitatif dan kualitatif. Pada penelitian ini tergolong penelitian confirmatory yaitu penelitian ini dilakukan untuk menguji model yang sebelumnya telah diuji berdasarkan teori yang telah ada.

\section{Data dan Sumber Data}

Pada penelitian ini data yang digunakan berasal dari data primer dan data sekunder.

1. Data Primer

DataPrimer atau Primary Data merupakan data yang dikumpulkan penelitin dan digunakan untuk tujuan tertentu dalam memecahkan suatu masalah (Malhotra 2007). Data primer ini sendiri diperoleh dari melakukan Wawancara, observasi dan survey. Penelitian ini lebih cenderung menggunakan metode survei. Metode penelitian survei merupakan metode pengumpulan data dimana data yang diperoleh melalui cara pengumpulan data dengan kuesioner yang dibagikan 
kepada responden. Alasan memilih menggunakan teknik survey sendiri adalah karena kebutuhan akan informasi yang dibituhkan, keterbatasan waktu dan biaya, serta karakteristik responden yang sesuai dengan permasalahn penelitian.

2. Data Sekunder

Data sekunder atau Secondary Data merupakan data yang telah dikumpulkan dalam penelitian untuk suatu tujuan selain masalah yang sedang dihadapi (Malhotra,2007). Data sekunder dapat diklasifikasikan kedalam 2 bentuk yaitu data internal dan data eksternal. Data internal merupakan data yang tersedia dalam suatu organisasi dimana riset itu dilakukan. Sedangkan data eksternal merupakan data yang dihasilkan dari sumber-sumber lain diluar organisasi. Pada penelitian ini penulis cenderung menggunakan data sekunder eksternal yang diperoleh dari buku-buku, jurnal, internet, serta sumber lain yang dianggap dapat mendukung penelitian.

\section{Metode Pengumpulan Data}

\section{Kuesioner (Angket)}

Data yang digunakan dalam penelitian ini diperoleh melalui metode kuesioner yaitu teknik pengumpulan data yang dilakukan dengan cara memberi kuesioner atau seperangkat pertanyaan atau pernyataan tertulis kepada responden (Sugiyono, 2001). Populasi dan Sampel

populasidalam penelitian ini adalah semua pelanggan dari Indosat IM3 yang berdomisili di Solo dan sekitarnya. Pengambilan sampel dilakukan dengan kriteria responden yang dapat dijadikan sebagai sampel adalah sebagai berikut :

a. Pelanggan Indosat IM3 yang berdomisili di Solo dan Sekitarnya.

b. Pelanggan Indosat IM3 yang menggunakan layanan Indosat IM3 selama kurun waktu lebih dari 6 bulan.

c. Pelanggan pernah mengalami kegagalan layanan.

d. Pelanggan pernah menyampaikan keluhannya terkait dengan kegagalan layanan kepada perusahaan yang bersangkutan (PT Indosat,tbk).

Sampel yang diambil sejumlah 100 responden. Hal ini didasarkan pada pernyataan Ghozali (2001) bahwa metode analisis sampel kecil direkomendasikan $>30$ dan sampel besar direkomendasikan $>200$.

\section{Instrumen Penelitian Dan Skala Pengukuran}

Variabel penelitian diukur dengan menggunakan instrumen kuesioner. Variabel Service Recovery menggunakan instrumen yang dikembangkan oleh Tax et al.,(Kau dan Loh,2006) yang mengajukan 3 dimensi pemulihan kegagalan pelayanan pada pengguna jasa e-services, yakni Procedural Justice, Interactional Justice, dan Distributive Justice. Masing-masing item diukur dengan menggunakan skala Likert.

\section{HASIL DAN PEMBAHASAN}

\section{Hasil Analisis Data}

\section{Karakteristik Responden}

Berdasarkan hasil dari penyebaran kuesioner sebanyak 150 responden mendapatkan hasil bahwa, 100 responden tidak mengajukan keluhan pada Galeri Indosat dan 50 responden lainnya mengajukan keluhan pada Galeri Indosat. Sedangkan menurut jenis kelamin, pada penelitian ini didominasi oleh responden perempuan sebanyak 88 responden. Dalam kategori usia, responden terbanyak adalah antara 15-20 tahun. Sedangkan dalam hal pekerjaan, dalam penelitian ini didominasi oleh mahasiswa dengan pendidikan terakhir SMA. Penelitian ini juga menghasilkan informasi bahwa jumlah responden menggunakan jenis layanan pra bayar lebih besar daripada pengguna pasca bayar dan lama penggunaan layanan didominasi oleh pelanggan dengan lama penggunaan antara 1-2 tahun penggunaan layanan.

\section{Uji Instrumen Validitas dan Uji Reliabilitas}

Penelitian ini menghasilkan informasi bahwa pada uji validitas variabel procedural justice, interactional justice, distributive justice, dengan nilai $\mathrm{r}$ tabel sampel taraf signifikansi 0,05 adalah 0,279 menunjukkan hasil bahwa semua pertanyaan variabelvariabel tersebut semuanya valid, karena nilai $r$ hitung $>r$ tabel $(0,279$ yang diperoleh dari 
$\mathrm{r}$ tabel dengan $\mathrm{N}=50$ ). Sedangakan variabel lain seperti satisfaction, trust, dan loyalty dengan nilai $r$ tabel sampel taraf signifikansi 0,05 adalah 0,159 menunjukkan bahwa semua butir pertanyaan variabel-variabel tersebut semuanya juga valid, karena nilai $r$ hitung $>r$ tabel $(0,159$ yang diperoleh dari $r$ tabel dengan $\mathrm{N}=150$ ). Uji Reliabilitas menunjukkan bahwa nilai keseluruhan Cronbach's Alpha semua variabel dalam penelitian ini $>0,60$ maka semua variabel dinyatakan reliabel karena nilai $r$ hitung $>r$ tabel.

\section{Analisis Regresi Linear Berganda}

Analisa ini digunakan untuk mengetahui besarnya pengaruh variabel procedural justice, interactional justice, dan distributive justice terhadap kepercayaan dan loyalitas pelanggan serta kepuasan sebagai variabel intervening. Dengan menggunakan program SPSS.20 koefisien regresi yang diperoleh dari hasil pengolahan data adalah sebagai berikut.

\section{Hasil Analisis Regresi Berganda}

a. Uji T-test

Uji t pada dasarnya menunjukkan seberapa jauh pengaruh satu variable independen secara individual dalam menerangkan variasi variabel independen. Jika nilai signifikan a $<0,05$ maka dapat dikatakan bahwa terdapat pengaruh yang signifikan antara variabel independen dengan variabel dependen secara individu. Berikut ini merupakan hasil uji T-test pada masing-masing regresi. Hasil analisis regresi model 1 tabel menunjukkan bahwa t hitung procedural justice adalah sebesar 2,384 dengan signifikansi t 0,021 (signifikan) dan koefisien regresi sebesar 0,485. Variabel interactional justice adalah sebesar 1,782 dengan signifikansi t 0,081 (tidak signifikan) dan koefisien regresi sebesar 0,415. Dan variabel distributive justice adalah sebesar 0,473 dengan signifikansi $t$
0,639 (tidak signifikan) dan koefisien regresi sebesar 0,076. Hal ini menunjukkan bahwa variabel distributive justice dan interactional justice yang mempunyai pengaruh positif tetapi tidak signifikan terhadap kepuasan pelanggan. Sedangkan variabel lain seperti procedural justice memiliki pengaruh positif dan signifikan terhadap kepuasan pelanggan.

Hasil analisis regresi model 2 menunjukkan bahwa thitung satisfaction/kepuasan pelanggan adalah sebesar 8,206 dengan signifikansi $\mathrm{t}$ 0,000 (signifikan) dan koefisien regresi sebesar 0,384 . Hal ini menunjukkan bahwa variabel satisfaction/ kepuasan pelanggan mempunyai pengaruh positif dan signifikan terhadap Trust atau kepercayaan pelanggan. Hasil analisis regresi model 3 menunjukkan bahwa t hitung satisfaction/kepuasan pelanggan adalah sebesar 8,426 dengan signifikansi t 0,000 (signifikan) dan koefisien regresi sebesar 0,524. Hal ini menunjukkan bahwa variabel satisfaction/ kepuasan pelanggan mempunyai pengaruh positif dan signifikan terhadap Loyalty atau loyalitas pelanggan.

\section{b. Uji F-test}

Dari tabel 8, nilai $\mathrm{F}$ hitung model 1 adalah sebesar 13,646 dengan taraf signifikansi 0,000 lebih kecil daripada 0,05 . Hal ini menunjukkan bahwa procedural justice, interactional justice, dan distributive justice secara bersama-sama berpengaruh terhadap kepuasan pelanggan. Nilai F hitung model 2 adalah sebesar 67,334 dengan taraf signifikansi 0,000 lebih kecil daripada 0,05. Hal ini menunjukkan bahwa satisfaction/ kepuasan pelanggan berpengaruh terhadap kepercayaan pelanggan. Dari tabel 10, nilai $\mathrm{F}$ hitung adalah sebesar 71,001 dengan taraf signifikansi 0,000 lebih kecil daripada 0,05 . Hal ini menunjukkan bahwa satisfaction/ kepuasan pelanggan berpengaruh terhadap loyalitas pelanggan.

Tabel 4.1 Hasil Pengujian Model

\begin{tabular}{lccc}
\hline \multicolumn{1}{c}{ Variabel } & Model 1 & Model 2 & Model 3 \\
\hline Constant & 3.940 & 5.347 & 6.864 \\
Uji t pada $\mathrm{X}_{1}$ & $* * 2.384$ & - & - \\
Uji t pada $\mathrm{X}_{2}$ & 1.782 & - & - \\
Uji t pada $\mathrm{X}_{3}$ & .473 & - & - \\
Uji t pada Z & & $* * 8.206$ & $* * 8.426$ \\
$\mathrm{R}^{2}$ & .436 & .308 & .320 \\
$\mathrm{~F}$ & $* * * 13.646$ & $* * * 67.334$ & $* * * * 71.001$ \\
\hline \multicolumn{4}{c}{ Signifikansi } \\
\end{tabular}




\section{Uji Koefisien Determinasi}

Koefisien determinasi () pada intinya mengukur seberapa jauh kemampuan model dalam menerangkan variasi variabel independen. Nilai Adjusted $R$ Square dalam analisis regresi I adalah sebesar 0,436 berarti kepuasan pelanggan dipengaruhi sebesar $43,6 \%$ oleh variabel procedural justice, interactional justice, dan distributive justice. Sisanya sebesar 56,4\% dipengaruhi oleh variabel lain di luar penelitian. Pada model 1 Adjusted $R$ Square menunjukkan koefisien determinasi atau peranan varian luar independen dalam hubungan dengan variabel dependen. Angka Adjusted R Square pada model sebesar 0,308 menunjukkan bahwa hanya $30,8 \%$ variabel dependen atau kepercayaan pelanggan yang bisa dijelaskan oleh variabel independen (satisfaction), sisanya dijelaskan oleh faktor lain. Adjusted R Square model menunjukkan koefisien determinasi atau peranan variance luar independen dalam hubungan dengan variabel dependen. Angka Adjusted $R$ Square sebesar 0,320 menunjukkan bahwa hanya 32\% variabel dependen atau loyalitas pelanggan yang bisa dijelaskan oleh variabel independen (satisfaction), sisanya dijelaskan oleh faktor lain.

\section{PEMBAHASAN HASIL PENELITIAN DAN DISKUSI}

\section{Pengaruh Procedural Justice terhadap Kepuasan atas Service Recovery}

Hasil pengujian hipotesis pertama dengan analisis regresi berganda memperoleh nilai $F$ hitung sebesar 13,646 diterima pada taraf signifikansi $5 \%(\mathrm{p}<0,05)$. Nilai t hitung procedural justice adalah sebesar 2,384 dengan signifikansi t 0,021 (signifikan) dan koefisien regresi sebesar 0,485. Maka H1.a diterima.

Hasil penelitian menunjukkan bahwa procedural justice berpengaruh langsung, positif dan signifikan terhadap kepuasan pelanggan. Hal ini menunjukkan bahwa semakin baik procedural justice yang diberikan kepada pelanggan operator seluler Indosat IM3 setelah terjadinya kegagalan layanan jasa, maka semakin tinggi kepuasan pelanggan. Ketika terjadi kegagalan layanan dan pelanggan mengadu pada Indosat, proses yang dilalaui mulai dari melapor sampai masalah dapat ditangani sangat cepat dan baik. Selain itu karyawan di Galeri Indosat merespon dengan cepat dan tanggap, sehinggan pelanggan tidak mengalami kesulitan dalam mengadukan keluhan dan hasilnya sesuai ekspektasi mereka. Hasil penelitian ini menunjukkan bahwa untuk mendapatkan kepuasan dari pelanggan, perusahaan harus memperhatikan faktor prosedur-prosedur yang tepat dalam menangani keluhan.

Hasil penelitian ini konsisten dengan hasil penelitian terdahulu yang dilakukan oleh Kau dan Loh (2006); Nursyamsiah dan Virgostin (2011); dan Siu et al., (2013) masing-masing menyatakan bahwa, procedural justice memiliki pengaruh positif dan signifikan terhadap kepuasan pelanggan setelah penanganan keluhan.

\section{Pengaruh Interactional Justice terhadap Kepuasan atas Service Recovery}

Hasil pengujian hipotesis kedua dengan analisis regresi berganda memperoleh nilai F hitung sebesar 13,646 diterima pada taraf signifikansi $5 \% \quad(p<0,05)$. Nilai $t$ hitung interactional justice adalah sebesar 1,782 dengan signifikansi t 0,081 (tidak signifikan) dan koefisien regresi sebesar 0,415. Maka H1.b ditolak.

Hal ini menandakan bahwa interactional justice memiliki pengaruh langsung, positif tetapi tidak signifikan terhadap kepuasan pelanggan. Hasil penelitian ini menunjukkan bahwa untuk mendapatkan kepuasan dari pelanggan, perusahaan harus memperhatikan faktor interaksi personal antara karyawan dan pelanggan dalam proses penanganan keluhan. Dalam konteks jasa operator seluler melalui Galeri Indosat ini, Indosat memiliki karyawankaryawan baik dalam melayani keluhan para pelanggan, hal itu terbukti dengan perhitungan koefisien regresi yang terbukti positif, akan tetapi hasil tersebut kurang berdampak signifikan terhadap kepuasan pelanggan.

Hasil penelitian ini konsisten dengan hasil penelitian terdahulu yang dilakukan oleh Kau dan Loh (2006) yang menyatakan bahwa, interactional justice memiliki pengaruh positif tetapi signifikansi terhadap kepuasan pelanggan cenderung rendah. Sedangkan hasil penelitian yang tidak sejalan dengan 
penelitian ini dikemukakan oleh Nursyamsiah dan Virgostin (2011); Siu et al., (2013) dan Mostafa (2014) masing-masing menyatakan bahwa, interactional justice memiliki pengaruh positif dan signifikan terhadap kepuasan pelanggan setelah penanganan keluhan.

\section{Pengaruh Distributive Justice terhadap Kepuasan atas Service Recovery}

Hasil pengujian hipotesis ketiga dengan analisis regresi berganda memperoleh nilai $\mathrm{F}$ hitung sebesar 13,646 diterima pada taraf signifikansi $5 \% \quad(\mathrm{p}<0,05)$. Nilai $\mathrm{t}$ hitung distributive justice adalah sebesar 0,473 dengan signifikansi t 0,639 (tidak signifikan) dan koefisien regresi sebesar 0,076. Maka H1.c ditolak

Hal ini berarti bahwa distributive justice memiliki pengaruh langsung, positif tetapi tidak signifikan terhadap kepuasan pelanggan. Hasil penelitian ini menunjukkan bahwa untuk mendapatkan kepuasan dari pelanggan, kompensasi yang diberikan kepada pelanggan haruslah lebih menarik dan lebih adil, karena dalam kasus ini pelanggan cenderung kurang tertarik dengan kompensasi yang diberikan atau ditawarkan oleh perusahaan. Oleh karena itu perusahaan harus lebih memperhatikan faktor-faktor distributive justice seperti lebih variatif dalam memberikan kompensasi agar tingkat kepuasan terhadap layanan jasa pada Indosat IM3 ini lebih meningkat.

Hasil penelitian ini konsisten dengan hasil penelitian terdahulu yang dilakukan oleh Mostafa (2014) yang menyatakan bahwa, distributive justice memiliki pengaruh positif tetapi signifikansi terhadap kepuasan pelanggan cenderung rendah. Sedangkan hasil penelitian yang tidak sejalan dengan penelitian ini dikemukakan oleh Kau dan Loh (2006); Nursyamsiah dan Virgostin (2011); dan Siu et al., (2013) masing-masing menyatakan bahwa, distributive justice memiliki pengaruh positif dan signifikan terhadap kepuasan pelanggan setelah penanganan keluhan.

\section{Pengaruh Satisfaction atas Service Recovery terhadap Kepercayaan}

Hasil pengujian hipotesis keempat dengan analisis regresi berganda memperoleh nilai $\mathrm{F}$ hitung sebesar 67,334 diterima pada taraf signifikansi 5\% $(\mathrm{p}<0,05)$. Nilai t hitung satisfaction adalah sebesar 8,206 dengan signifikansi t 0,000 (signifikan) dan koefisien regresi sebesar 0,384. Maka H2.a diterima.

Hasil ini berarti bahwa satisfaction memiliki pengaruh langsung, positif dan signifikan terhadap kepercayaan pelanggan. Hasil penelitian ini menunjukkan bahwa untuk mendapatkan kepercayaan dari pelanggan, perusahaan harus memperhatikan faktor kepuasan terhadap penanganan keluhan terlebih dahulu barulah tercipta kepercayaan dari pelanggan. Kepuasan dari pelanggan dapat tercipta dengan adanya penanganan terhadap keluhan dengan tepat dan sesuai ekspektasi pelanggan, serta dapat tercipta dengan kesediaan pelanggan untuk terus menggunakan layanan dari operator seluler seperti Indosat IM3. Kepuasan pelanggan Indosat IM3 ini akan berdampak langsung terhadap kepercayaan para pelanggan, dan dari kepercayaan tersebut akan tercipta pelanggan yang loyal.

Hasil penelitian menunjukkan bahwa satisfaction berpengaruh langsung, positif dan signifikan terhadap kepercayaan pelanggan. Konsisten dengan hasil penelitian terdahulu yang dilakukan oleh Choi dan La (2013). Dalam penelitian ini dikemukakan bahwa satisfaction with recovery memiliki pengaruh positif dan signifikan terhadap kepercayaan pelanggan.

\section{Pengaruh Satisfaction atas Service Recovery terhadap Loyalitas}

Hasil pengujian hipotesis kelima dengan analisis regresi berganda memperoleh nilai F hitung sebesar 71,001 diterima pada taraf signifikansi $5 \% \quad(p<0,05)$. Nilai $t$ hitung satisfaction adalah sebesar 8,426 dengan signifikansi t 0,000 (signifikan) dan koefisien regresi sebesar 0,524. Maka H2.b diterima.

Hal tersebut berarti satisfaction memiliki pengaruh langsung, positif dan signifikan terhadap loyalitas pelanggan. Hasil penelitian ini menunjukkan bahwa untuk mendapatkan pelanggan yang loyal, maka perusahaan harus memperhatikan faktor kepuasan terhadap penanganan keluhan terlebih dahulu barulah tercipta loyalitas dari pelanggan. Pelanggan yang loyal dapat tercipta dari baiknya layanan yang diberikan oleh perusahaan dalam hal ini 
Indosat IM3, yang sesuai dengan harapan dan ekspektasi dari pengguna layanan. Dengan adanya layanan yang baik pasca keluhan ataupun sebelum keluhan maka pelanggan dengan sendirinya akan puas kemudian akan menjadi percaya dan hasil akhir yang diharapkan adalah menjadi loyal terhadap perusahaan dalam hal ini adalah Indosat IM3.

Hasil penelitian ini konsisten dengan hasil penelitian terdahulu yang dilakukan oleh Kau dan Loh (2006); Choi dan La (2013); Siu et al.,(2013); dan Dimyati (2015). Dalam penelitian ini masing-masing menyatakan bahwa satisfaction with recovery memiliki pengaruh positif dan signifikan terhadap loyalitas pelanggan.

Dari berbagai pemaparan dan pembahasan hasil pengujian hipotesis diatas, dapat disimpulkan dalam tabel sebagai berikut :

Berdasarkan nilai t value pada analisis regresi I dari data penelitian yang telah diolah menunjukkan bahwa konstruk yang memberikan pengaruh positif dan signifikan terbesar terhadap kepuasan/ satisfaction adalah hanya procedural justice. Artinya prediktor yang paling dominan mempengaruhi kepuasan pelanggan/ satisfaction adalah procedural justice. Konstruk lain seperti interactional justice dan distributive justice. Berpengaruh positif tetapi kurang signifikan terhadap kepuasan pelanggan/ satisfaction.

Dari hasil penelitian didapatkan suatu temuan menarik yaitu bahwa kepuasan pelanggan/ satisfaction pada Indosat IM3 hanya dapat disebabkan oleh faktor procedural justice. Procedural justice dalam hal ini meliputi baiknya prosedur-prosedur yang dilakukan oleh perusahaan dalam menangani keluhan yang disampaikan oleh pelanggan, kemudahan akses pelanggan dalam menyampaikan keluhan, dan kinerja yang cepat tanggap yang dilakukan oleh karyawan di Galeri Indosat dalam menangani keluhan pelanggan. Hal ini hampir serupa dengan pendapat menurut Tax et al.,(Rashid dan Ahmad, 2014) yang menyatakan bahwa "Procedural justice meliputi process control, decision making, accessibility, timing/ speed, dan flexibility". Sedangkan konstruk lain seperti interactional justice dan distributive justice yang merupakan bentuk lain dari service recovery yang dilakukan Galeri Indosat dianggap kurang mampu membuat pelanggan puas. Hal ini mungkin disebabkan oleh interaksi yang kurang selaras antara karyawan Galeri Indosat dengan pelanggan, seperti misalnya karyawan kurang komunikatif dengan pelanggan, penjelasan dari karyawan kurang sesuai dengan harapan pelanggan, ataupun sikap karyawan yang dianggap kurang berempati ataupun kurang sopan terhadap pelanggan. Hal-hal tersebut yang mungkin membuat interactional justice yang merupakan bentuk service recovery kurang berprngaruh signifikan terhadap kepuasan. Sedangkan dalam hal lain seperti pemberian kompensasi dalam bentuk misalnya pemberian discount, free gift, coupon, refunds, dan sebagainya yang merupakan bentuk dari interactional justice dianggap kurang menarik atau kurang bedampak signifikan terhadap kepuasan pelanggan. Oleh karena itu Indosat melalui Galeri Indosat haruslah lebih berusaha meningkatkan kinerja kualitas dalam hubungan personal antara karyawan dan pelanggan (interactional justice) dan juga membuat tampilan yang lebih menarik dan lebih variatif terhadap kompensasi yang akan diberikan (distributive justice).

Hasil lain didapatkan temuan bahwa kepuasan dari pelanggan Indosat IM3 sangat berpengaruh signifikan terhadap kepercayaan dan loyalitas pelanggan. Temuan ini tidaklah mengherankan sebab pada banyak penelitian sebelumya seperti yang dilakukan Kau dan Loh (2006), Siu et al.,(2013), dan Dimyati (2013) dikemukakan bahwa kepuasan berpengaruh positif dan signifikan terhadap loyalitas, sedangakan kepuasan berampak positif dan signifikan dikemukakan oleh Choi dan $\mathrm{La}$ (2013). Dari temuan diatas hasil penelitian ini juga berkontribusi dalam membuktikan bahwa kepuasan pelanggan berpengaruh terhadap kepercayaan, dan juga berpengaruh terhadap loyalitas pelangan.

\section{KESIMPULAN DAN SARAN}

Berdasarkan hasil penelitian, analisis data dan pembahasan pada penelitian ini, maka dapat diambil kesimpulan sebagai berikut :

1. Pengaruh procedural justice terhadap kepuasan pelanggan Indosat IM3 di wilayah Solo dan sekitarnya adalah positif dan signifikan. Hal ini menunjukkan bahwa semakin baik procedural justice 
yang diberikan, maka semakin tinggi kepuasan pelanggan.

2. Pengaruh interactional justice terhadap kepuasan pelanggan Indosat IM3 di wilayah Solo dan sekitarnya adalah positif dan tetapi kurang signifikan. Hasil penelitian ini menunjukkan bahwa untuk mendapatkan kepuasan dari pelanggan, perusahaan harus memperhatikan faktor interaksi anata karyawan dan pelanggan dengan lebih mendalam agar tercipta kepuasan dari pelanggan.

3. Pengaruh distributive justice terhadap kepuasan pelanggan Indosat IM3 di wilayah Solo dan sekitarnya adalah positif dan tetapi kurang signifikan. Hasil penelitian ini menunjukkan bahwa untuk mendapatkan kepuasan dari pelanggan, perusahaan harus lebih memperhatikan kompensasi-kompensasi apa yang menarik untuk pelanggan agar dapat mempengaruhi kepuasan pelanggan.

4. Pengaruh satisfaction terhadap kepercayaan pelanggan Indosat IM3 di wilayah Solo dan sekitarnya adalah positif dan signifikan. Hasil penelitian ini menunjukkan bahwa untuk mendapatkan kepercayaan dari pelanggan, perusahaan harus memperhatikan faktor kepuasan terhadap penanganan keluhan terlebih dahulu barulah tercipta kepercayaan dari pelanggan.

5. Pengaruh satisfaction terhadap loyalitas pelanggan Indosat IM3 di wilayah Solo dan sekitarnya adalah positif dan signifikan. Hasil penelitian ini menunjukkan bahwa untuk mendapatkan pelanggan yang loyal, maka perusahaan harus memperhatikan faktor kepuasan terhadap penanganan keluhan terlebih dahulu barulah tercipta loyalitas dari pelanggan.

Berdasarkan hasil penelitian dan kesimpulan yang telah diambil, maka dapat dikemukakan beberapa saran sebagai berikut:

1. PT Indosat perlu meningkatkan kepuasan pelanggan terutama melalui dimensi procedural justice dalam upaya pemulihan layanan sehingga pelanggan akan memberikan evaluasi yang baik,percaya terhadap perusahaan dan menjadi pelanggan yang loyal terhadap perusahaan.

2. PT Indosat perlu meningkatkan kepuasan pelanggan dengan memberikan penurunan tarif, kompensasi yang lebih menarik atas kegagalan layanan, perbaikan jaringan yang sering bermasalah dengan tetap mempertahankan kualitas pelayanan yang bermutu dan meningkatkan pelayanannya.

3. PT Indosat harus berusaha mencapai loyalitas pelanggan, hal ini dapat dilakukan dengan mengedepankan peningkatan kualitas pelayanan di Galeri Indosat dengan pelayanan yang cepat, tanggap, handal, terjamin, dan berempati.

4. Bagi penelitian mendatang perlu menambahkan variabel lain yang diduga memiliki kaitan dengan kepercayaan dan loyalitas pelanggan, seperti sosial budaya masyarakat, faktor intelektual pelanggan, dan faktor karakteristik pelanggan lainnya.

5. Bagi penelitian mendatang perlu lebih memfokuskan diri pada kepuasan atas service recovery, karana dalam penelitian ini cenderung kepuasan dengan definisi umum yang memperoleh perhatian dari responden dengan jumlah responden sebanyak 100 orang, sedangkan kepuasan dengan definisi atas service recovery hanya mendapat perhatian sebanyak 50 orang responden.

\section{DAFTAR PUSTAKA}

Badawi. 2012. International Journal of Inovation, Management, and Technology. Vol.3, No.5.

Badiana, Leanny. 2012. Analisis Hubungan Antara Buruknya Kegagalan Jasa, Keadilan Pemulihan Jasa, dan Persepsi Biaya Peralihan dengan Loyalitas Pelanggan: Studi Kasus Pada Indosat IM3. Depok : Universitas Indonesia.

Choi, Beomjoon. dan Suna La. (2013). The Impact of Corporate Social Responsibility (CSR) an Customer Trust in the Restoration of Loyalty After Service Failure and Recovery. Journal of Service Marketing. Vol.27/3, pp 223233. 
Dimyati, Mohamad. 2015. The Role of Customer Satisfaction in Mediating Marketing Communication Effect on Customer Loyalty. Research World: Journal of Art, Science and Commerce:, International Refereed Research Journal. Vol.VI, Issue.4(1).

Ferdinand, Augusty T.,2006. Metode Penelitian Manajemen : Pedoman Penelitian untuk Penulisan Skripsi, Tesis dan Desertasi, BP Undip, Semarang.

Ghozali, Imam. 2001. Aplikasi Analisis Multivariate dengan Program SPSS, BP UNDIP, Semarang.

Ghozali, Imam. 2005. Aplikasi Analisis Multivariate dengan Program SPSS edisi 3, BP UNDIP, Semarang.

Griffin, Jill, 2006, Customer Loyalty: How to Earn It, How to Keep It, Simon and Chuster, Inc., New York.

Kau, A., Elizabeth. W. Loh. 2006. The Effect of Service recovery on Consumer Satisfaction: a Comparison Between Complainant and Non- Complainants. Journal of Services Marketing.Vol.20 (2), pp: 101-111

Kotler, Philip. And Kevin Lane Keller. 2006. Marketing Management 12e. Pearson International Edition, Upper Saddle River, New Jersey: Pearson Prentice Hall Inc.

Lovelock, Christoper, dan Wright, K, Lauren. (2005), Manajemen Pemasaran Jasa, Penerjemah Agus Widyantoro, Penerbit Indeks, Jakarta.

Mostofa, Rania. Lages, C.R. dan Saaksjarvi, Maria. The CURE Scale: a Multidimensional Measure of Service Recovery Strategy. Journal of Service Marketing. Vol 28(4) ,pp 300-310.

Naresh K. Malhotra. 2004. Riset Pemasaran Jilid I, Indeks, Jakarta.

Naresh K. Malhotra. 2007. Riset Pemasaran Jilid III, Indeks, Jakarta.
Nursyamsiah, Siti dan Oryza Dian Virgostin. 2011. Pengaruh Service Recovery Terhadap Loyalitas Yang Dimediasi Kepuasan Pelanggan", Jurnal Bisnis dan Ekonomi.Vol.2, No.2,pp 136-147.

Ogbonna, C.O., Igbojekwe. dan Polycarp. 2015. Evaluation of Service Recovery Strategies In Some Hotels In Lagos Metropolis, Lagos, Nigeria. Indiana Journal of Commerce and Management Studies. Vol.6, Issue.2.

Rashid, Muhammad H.A.dan Fauziah Sh.Ahmad. 2014. The Role of Recovery Satisfaction on Relationship between Service Recovery and Brand Evangelism: A Conceptual Framework. International Journal of Inovation, Management, and Technology. Vol.5, No.5.

Santoso, S., 2000, Buku Latihan SPSS Statistik Parametrik, PT. Elex Media Komputindo, Kelompok Gramedia, Jakarta.

Siu, N.Y.M., Zhang, T.J.F. dan Yau, C.Y.J. 2013. The Roles of Justice and Customer Satisfaction in Customer Retention: A Lesson from Service Recovery. Journal of Business Ethnics. Vol.114, pp 675678.

Sugiyono. 2001. Metode Penelitian Bisnis, Alfabeta, Bandung.

Sugiyono. 2004. Metode Penelitian Bisnis, Alfabeta, Bandung.

Susetyo , Waskito Budi. 2010. Pengaruh Kualitas Layanan PT Indosat Terhadap Loyalitas Pelanggan IM3 Di Wilayah Kabupaten Wonogiri Dengan Kepuasan Sebagai VAriabel Mediasi. Surakarta : Universitas Sebelas Maret.

Sutisna. 2003. Perilaku Konsumen dan Komunikasi Pemasaran, PT Remaja Rosdakarya, Bandung.

Tjiptono, Fandy, 2002, Strategi Bisnis, Edisi Pertama. Penerbit Andi, Yogyakarta. 
www.id.techinasia.com/laporan-finansialoperator-gsm-dan-cdma-terbesar-diindonesia-q1-2014/ diakses pada 26 September 2016.

Zeithamal, Valerie A., Mary Jo Bitner. dan
Dawayne D. Gemler. 2006. Service Marketing :Integrating Customer Focus Across the Firm.4thed.Mc.New York: Graw Hill. 